\title{
Urban Growth Evaluation by Coupling Descriptive Analysis and Zipf's Rank-Size Model in Parakou (Benin)
}

\author{
Maurille Paul Lanmandjèkpogni ${ }^{1, *}$, François De Paule Codo ${ }^{1}$, Benjamin Kouassi Yao ${ }^{2}$ \\ ${ }^{1}$ Laboratory of Water Science and Technology (LSTE), National Water Institute (INE), University of Abomey-Calavi, Abomey-Calavi, \\ Republic of Benin \\ ${ }^{2}$ Laboratory of Industrials Processes, Synthesis, Environment and New Energies, Process Group and Environment, Houphouet-Boigny \\ National Polytechnic Institute, Yamoussoukro, Ivory Coast \\ Email address: \\ Paul.maurille@yahoo.fr (M. P. Lanmandjèkpogni), fdepaule2003@gmail.com (F. De P. Codo), beyao@yahoo.fr (B. K. Yao) \\ ${ }^{*}$ Corresponding author
}

\section{To cite this article:}

Maurille Paul Lanmandjèkpogni, François De Paule Codo, Benjamin Kouassi Yao. Urban Growth Evaluation by Coupling Descriptive Analysis and Zipf's Rank-Size Model in Parakou (Benin). Urban and Regional Planning. Vol. 4, No. 1, 2019, pp. 1-8.

doi: $10.11648 /$ j.urp.20190401.11

Received: December 26, 2018; Accepted: January 25, 2019; Published: February 21, 2019

\begin{abstract}
Parakou occupies a strategic place in the socio-economic development of Benin due to its geographical position. Based on the Urban Land Registry data, and census data from the National Institute of Statistics and Applied Economics coupling with the statistical description and adjustment to the distribution Zipf rank-size model, allowed us to describe the urban hierarchy on the scale of Parakou localities over the period 1979 to 2013. The changes in densities of population occupation per decade show a tendency to sprawl from the 2000s and linear and quadratic adjustments are satisfactory (linear: $0.81 \leq \mathrm{R}^{2} \leq 0.95$ and quadratic: $\left.0.95 \leq \mathrm{R}^{2} \leq 0.98\right)$ and significant at $1 \%(\mathrm{P}$-value $=0.000)$ to $88 \%$. The linear coefficients of Pareto are continuously decreasing $(|\alpha|=1.749$ to $|\alpha|=0.831$ between 1979 and 2002), and reflect that the weight of big cities keeps an influence on small and medium-sized cities over this period, while a slight increase was observed in the courtyard of the decade from 2002 to 2013 ( $|\alpha|=0.861$ in 2013) and shows the effect of the creation of new districts with the gradual loss of the influence of the old districts of the central core. The results suggest that population growth of the city is occurred with urban sprawl controlled by exogenous factors of infrastructures or land type. Managements of spatial planning structures are then arrested in the guidelines to provide land for the human impacts control on natural resources of watersheds.
\end{abstract}

Keywords: Urban, Growth, Parakou, Spatial Planning

\section{Introduction}

The strong growth observed and predicted in developing countries, added to water resource pressures in the new global context justifies the interest of several research works in recent years [1-6]. The literature reports many elements indicating that groundwater and surface water quality, is largely controlled by urban emissions on watersheds [5-9]. In contrast, the need to preserve this resource is growing in terms of climate impacts manifest [10]. Despite the good knowledge of population and urban growth statistics on a global scale, the need for local initiative remains [11-12]. Developing countries, particularly Benin, are still poorly informed about their growth and urban sprawl, and often even the resulting extra costs for development needs [13]. Especially that the local conditions require the taking into account of specific and contextual information. Many studies have implemented the Zipf rank-size model with satisfactory regional results, but without being able to extract a cumulative knowledge that is easily transposable [14-16]. Consequently, anthropogenic pressures on local water resources are still poorly quantified [17]. In this context, the urban water cycle presents great risk of malfunction in the coming years if no management action of spatial planning is taken. According to voirion-canicio, it is for the scientific world, to help lay the prerequisites for designing relevant and robust urban sustainability indicators required for urban eve [18].

This work aims mainly to describe urban sprawl in order to 
define urban simple characterization parameters and is positioned in the context of defining urban sustainability indicator from the example of the city of Parakou in Benin, and whose modes of functioning exoka some worries regarding the control of spatial planning screws from the availability and long-term cost of producing drinking water.

\section{Material and Methods}

\subsection{Area Survey}

Parakou is the capital city in the northern part of Benin. Housed between the northern latitudes $9^{\circ} 15^{\prime}$ and $9^{\circ} 27^{\prime}$ and east longitude $2^{\circ} 31^{\prime}$ and $2^{\circ} 45^{\prime}$, the city has grown at a rate varied by decade, from the 1930 s to today. Upon observation empirically, the urban sprawl is mainly observed to the north with Ganou, Guema and neighbourhoods to the east with Ladji- Farani, Banikani, Titirou and then to the West with Albarika, Madina the reserved areas.

Largely found there are geological formations under the Precambrian basement arranged along a slightly undulating and can sometimes culminate around $390 \mathrm{~m}$ above sea level. Two sides drain the surface water; One to West to upper Ouémé and the other to the east Okpara, Ouémé tributary downstream at the exit of the town of Parakou.

Its fairly favourable terrain urbanization certainly explains the many development projects initiated in the 2000s with the advent of the Republic of Benin, the Millennium Challenge Account (MCA) and the proposed update of the Urban Land
Register (RFU). The municipal authority of the city continued in the same vein even after the program ended with the establishment of a GIS data base to a mapped land management.

Great with its forty urban neighbourhoods and devices spread across three districts, the city of Parakou has a usable space estimated $441 \mathrm{~km}^{2}$ and occupied about $40 \%$ on the date of June 2013 [19] with various level of urban development Climate plan Parakou is in a tropical dry zone with the alternation of a rainy season (May to October) and a dry season (November to March). The temperature range is low from May to October and during this time temperatures range on average around $25^{\circ} \mathrm{C}$. During the months from December to January (period harmattan) are recorded daily thermal amplitudes more pronounced $\left(35^{\circ} \mathrm{C}-40^{\circ} \mathrm{C}\right.$ in the early afternoon and $10^{\circ} \mathrm{C}-15^{\circ} \mathrm{C}$ at night). The average annual rainfall recorded at Parakou station are around $1170 \mathrm{~mm}$, concentrated in the period from July to September.

\subsection{Data Collection and Processing}

Although the analysis of land use per photo interpretation has given fairly satisfactory results, the fact remains that they are questionable since this approach does not fall absolutely in the domain of exact science [20]. This deficiency leads to realize a combined analysis of the evolution of the grip in relation to the evolution of the population on the basis of topographical information from the study area.

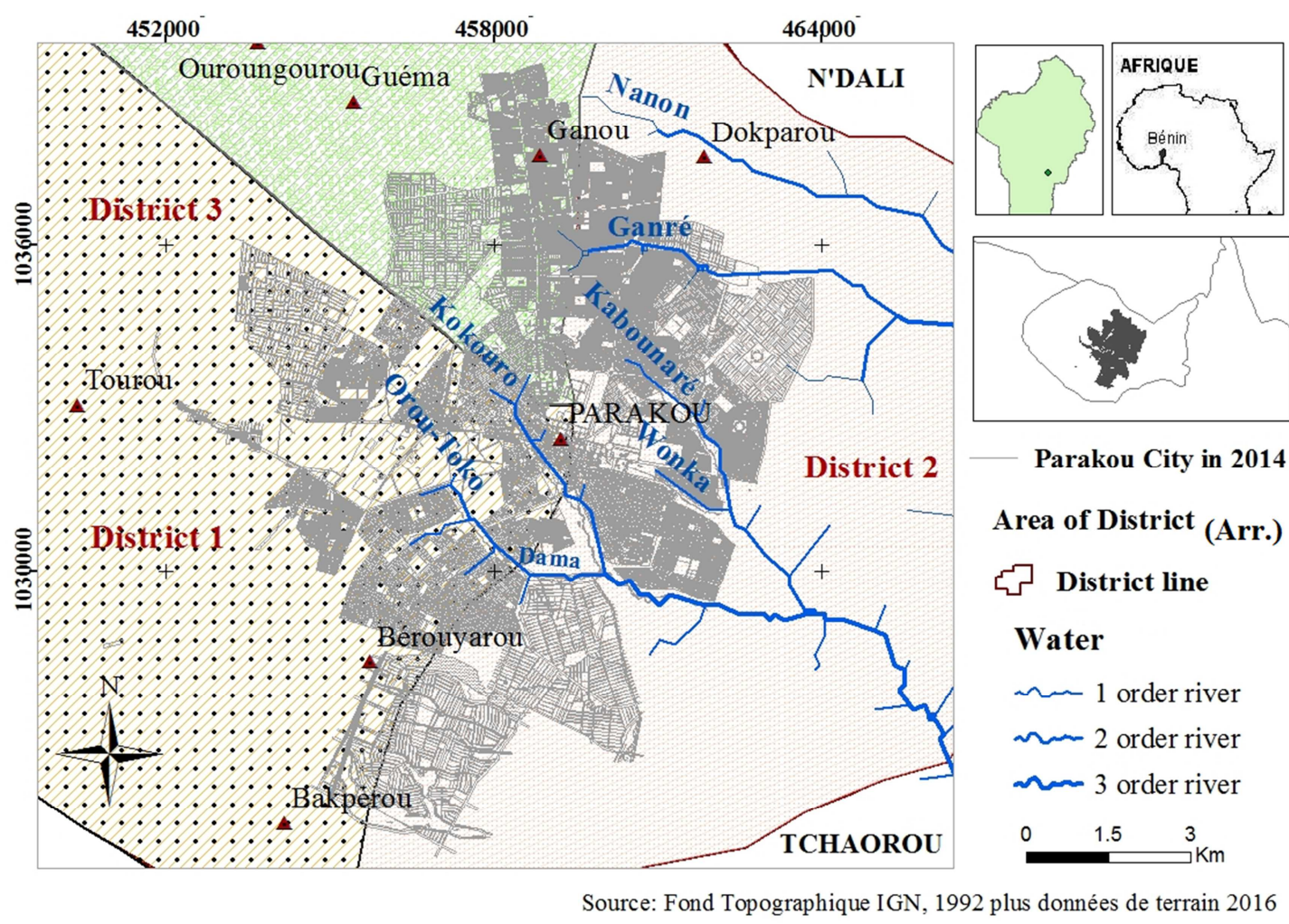

Figure 1. Study area.

For this, the work based on topographic plans AutoCAD from the RFU updated by the Millennium Challenge Account
(MCA) in 2004 and 2014, and supplemented by data from censuses INSAE the last two decades $\left(\mathrm{RGPH}_{2}, \mathrm{RGPH}_{3}\right.$ and 
$\mathrm{RGPH}_{4}$ ) one hand, and field information obtained at the town hall of the city of Parakou.

The processing of these data was to make a statistical analysis of description by medium and growth differentials derived from the theory of growth ratio on the number and area of the boroughs [21]. Then an evaluation was done by adjusting to Zipf's law at the neighbourhood level, the distribution of population size between 1979 and 2013. According to Zipf, the size and ranking of a population can be related as follows respectively "Eq. (1) and Eq. (2)" [22].

$$
\ln \left(R_{i t}\right)=\ln \left(A_{t}\right)-\alpha_{t} \ln \left(N_{i t}\right)+u_{i t}
$$

$R_{i t}$ And $N_{i t}$ designate rank and population size $\mathrm{i}$ at time $\mathrm{t}$ respectively, then $u_{i t}$ the error term on the adjustment. Despite the conditions observed in the application of this general law, this work was experimented on the scale of districts of the city and about Parakou, which are in the majority of small sizes. The quality of adjustment is searched by comparing its linear shape and quadratic with the coefficient of determination and the probabilities to significance levels of $1 \%$ and $5 \%$.

$$
\ln \left(R_{i t}\right)=\ln \left(A_{t}\right)-\alpha_{t} \ln \left(N_{i t}\right)+\beta_{t} \ln \left(N_{i t}\right)^{2}+u_{i t}
$$

\section{Results and Discussion.}

\subsection{Evaluation of Urban Growth in Parakou Between 1979 and 2013}

Parakou, also called the city of kobourou, is the third city with a special status as the legal texts of Benin, and as such, meets the minimum criteria of 100000 and not built on the 10 $\mathrm{km}$ disconnuité [23]. It occupies a similar economic position to that of Cotonou, the economic capital of the country to the northern region. This seems she worked for as an asset, given the important role it had to play at the time of colonial settlement in the Borgou. "Table 1" below, shows a temporal evaluation of the variations of some demographic indicators and growth which are: the density of the population, the total number of the people and the land are occupied by the population in the administrative division of the city.

The three periods of analysis are generally in order of the decade (10 years to 13 years). The $P_{-} 1$ phase is characterized by a densification of all the borough, as it indicates a positive steady growth of density differences in contrast to a lack of extension of the occupied areas. Although the P_2 phase, the population numbers have continued to grow, there is negative growth in densities despite the space consumption of more than 30 hectares between districts 1 and 3, and only 5ha in the district 2 . This phase is then characterized by a spreading districts 1 and 2, and a settlement of stability in the district 3 where the density did not change between 1992 and 2002 despite digital growth in 1243 inhabitants. The $\mathrm{P}_{-} 3$ phase representing the last decade census, reflects a recovery in consumption space with heavy lifts densities. It is observed during this phase, a large space consumption in districts 1 and 2; but increasing populations allowed past the situation of the spreading Phase P_2 (-32 hbt/ha and $-27 \mathrm{hbt} / \mathrm{ha})$ at a densification beginning $(+11$ and +9$)$. The same observation can be made at the third district with a slower rate than the other two districts. The variability shown in Table 1 between area occupied and population size indicates Parakou is a dispersive stage of growth where the population and habitat are always characterized by a load radius greater than one year to the other. According to Ramane study in 2009, spatial growth is centrifugal and refers to old kernel installed in the year 1949 with the shopping center and the administrative area around the Arzeke market. This analysis was made for Quebec cities before identifying thereafter, a trend towards polynuclear geographical space with the influences of the area of the industrialization [24].

Table 1. Time variation of density, population and area (1979-2013) (P_1: Period 1979-1992; P_2: Period 1992-2002; P_3: Period 2002-2013). Arr.

\begin{tabular}{|c|c|c|c|c|c|c|c|c|c|}
\hline \multirow{3}{*}{ Arr. } & \multicolumn{3}{|c|}{ density variation } & \multicolumn{3}{|c|}{ Population variation } & \multicolumn{3}{|c|}{ Area variation } \\
\hline & \multicolumn{9}{|c|}{ Period } \\
\hline & P 1 & P_2 & P 3 & P_1 & $\mathbf{P} 2$ & P 3 & P_1 & P_2 & P_3 \\
\hline Time period (ans) & 13 & 10 & 11 & 13 & 10 & 11 & 13 & 10 & 11 \\
\hline Arr. 1 & 17 & -32 & 11 & 772 & 1034 & 2451 & 0 & 38 & 56 \\
\hline Arr. 2 & 25 & -27 & 9 & 2094 & 1835 & 3286 & 0 & 5 & 95 \\
\hline Arr. 3 & 11 & 0 & 17 & 1727 & 1243 & 4190 & 0 & 35 & 14 \\
\hline
\end{tabular}
Arrondissement.

Table 2. Distribution of population by administrative $e^{l}$ division.

\begin{tabular}{llll}
\hline Arr. & Proportion de la population totale (\%) & Superficie $\left.\mathbf{( k m}^{\mathbf{2}}\right)$ & Densité hab. $/ \mathbf{k m}^{\mathbf{2}}$. \\
\hline Arr 1. & 44,7 & 267 & 295 \\
Arr 2. & 30,5 & 95 & 567 \\
Arr 3. & 24,7 & 79 & 2218 \\
\hline
\end{tabular}

Source: EAA, 2014

1 Status report Extract places on urban planning and the use of urban space, as part of the support to the development of the Master Plan of the city of Parakou Sanitation. Final report. (EAA, 2014). 


\subsection{Evaluation of Cast Zipf's Law in Parakou Between 1979 and 2013}

The overall growth of the population of the city can be adjusted to an exponential function "Figure 3" with respect to its variation since it was at 14,000 and 60,000 inhabitants between 1961 and 1979 [25].

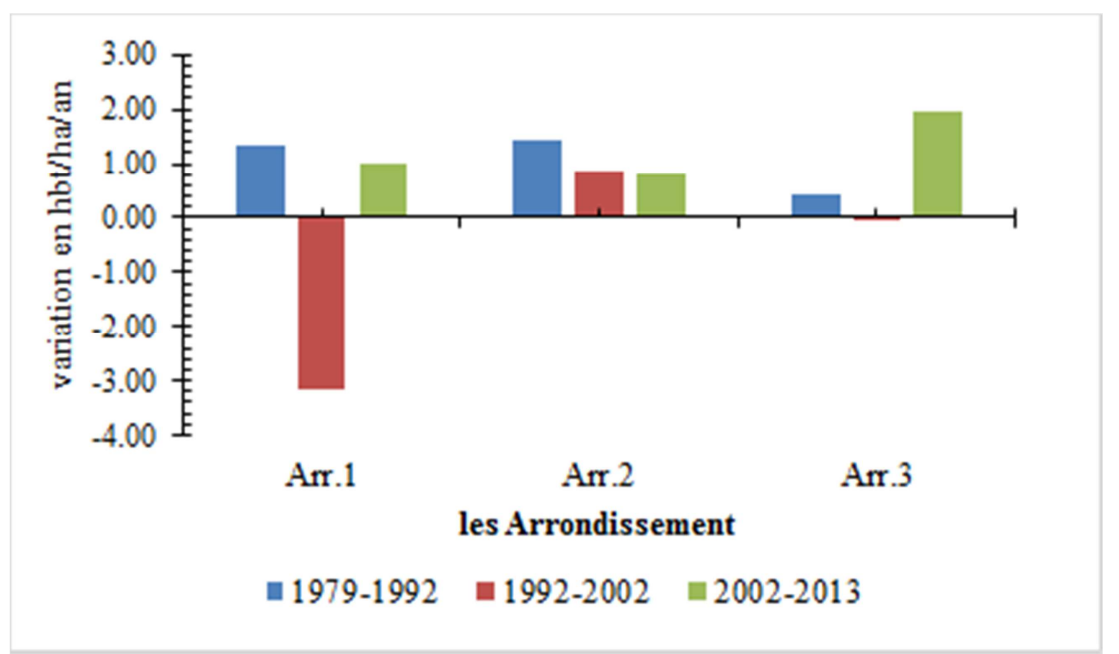

Figure 2. Annual average spatial variation of the occupation borough (1979-2013).

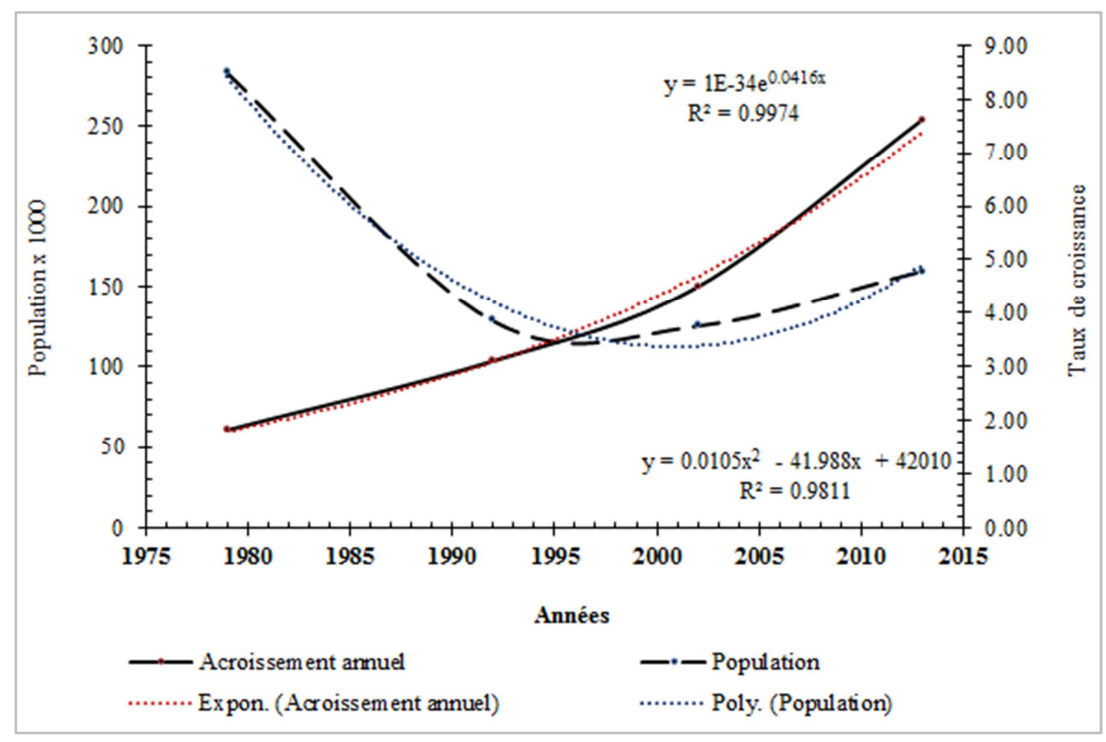

Figure 3. Change in the total population.

At the level of administrative division, the disparity of the spatial variation of average growth (Figure 2) is a component of the growth ratio [21]. It can be explained by the attractiveness and gradual facilitating access to essential services including: drinking water, electricity, bare land, property and personal security relief, distance to the city center...etc. [26]- [29]. The quality of the population trends of curves and the annual average growth rate $\left(\mathrm{R}^{2}=0.99\right.$ and $\mathrm{R}^{2}=0.98$ ), leads us to hypothesize that the logarithmic or square law distribution rank-population size can produce satisfactory results in the analysis of the distribution of districts in Parakou in the period 1979 to 2013.

For a first analysis of its kind in this study area, the original model Zipf is used despite the changed model. "Figure $4-7$ " respectively show the following for 1979,
1992, 2002 and 2013, the rank-size distribution of the districts of the city of Parakou following the linear and quadratic models.

With the linear model, the regression shows a remarkable softening of the slope of the line with a gradual decrease in absolute value of the coefficient $(1.749-0.831)$ between 1979 and 2002 before a weak recovery in $2013(\alpha=-0.861)$. The quality of regressions is satisfactory $\left(\mathrm{R}^{2}=0.89 \pm 0.043\right.$ in a $1 \%$ significance level). This is explained by the combined effect of the growth in the size of the sample on the one hand (27 in 1979 to $41^{2}$ in 2013), and the population sizes of the other neighbourhoods. The settlement

2 Extending Tourou is organized into six components (Tourou I, II, III, IV, V and VI) occupancy (Table 1) in this period despite the inclusion of large variations in size especially in districts 2 and 3 . 
neighbourhoods in Parakou is relatively low in the decades 70 to 90 with size very close quarters with a maximum of about 2500 inhabitants (average $1369 \pm 430$ to $1668 \pm 477$ inhabitants). The appearance of three new districts in 1992 did not have a great influence on the social organization as large neighbourhoods that time workforce continued to be populated. This period thus marks the first installation and urban growth area characterized by a relative balance of community social and administrative infrastructure in the old center and its immediate surroundings. Only in the aftermath of 1992, an outbreak of new neighbourhoods and repopulation of the old city districts caused a sudden drop of the slope in 2002 .

This reflects the impact of market Arzeke rebuilt in a more attractive style to the advent of democratic renewal in Benin Republic. The mono centric style with densification of neighbourhoods studied large central core has clearly highlighted with a larger number of medium and small effective areas $(1484 \pm 682$ to $4718 \pm 15325)$.

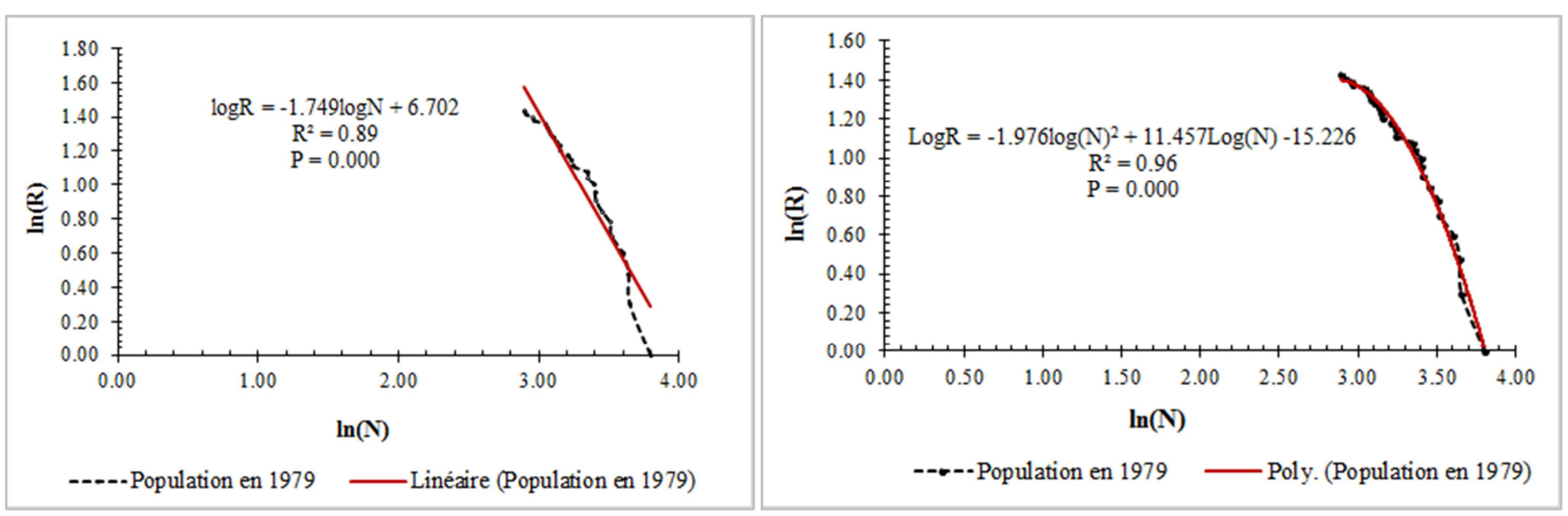

Figure 4. Linear and quadratic adjustment of Parakou districts in 1979. (Sample size: 27).
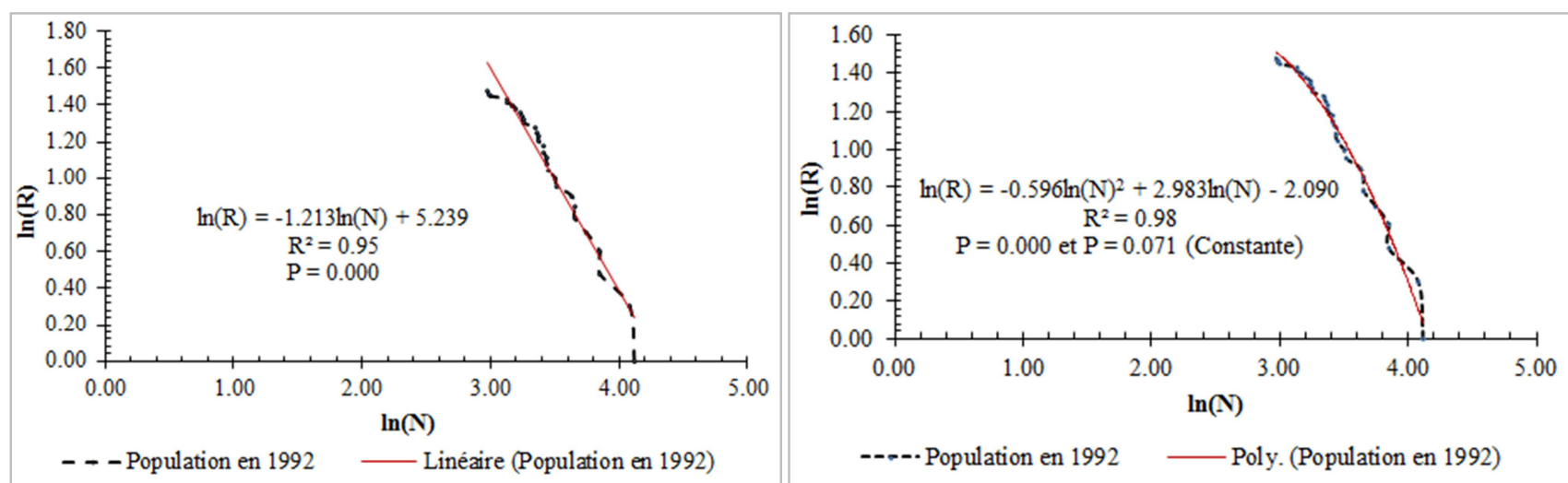

Figure 5. Linear and quadratic adjustment of Parakou districts in 1992. (Sample size: 30).

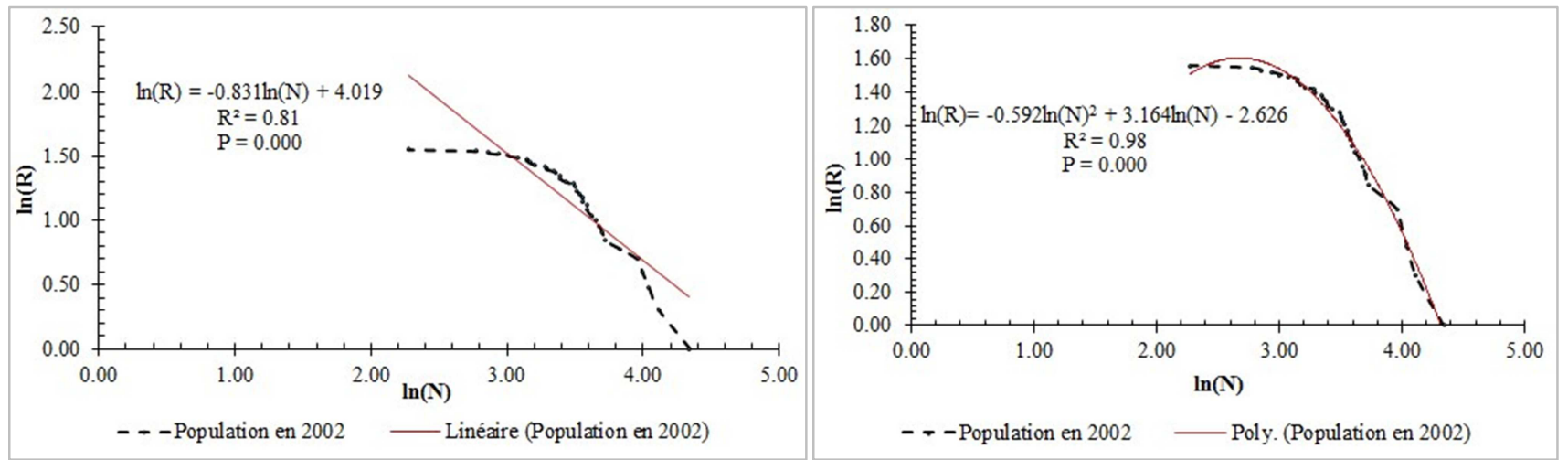

Figure 6. Linear and quadratic adjustment of Parakou districts in 2002. (Sample size: 36). 


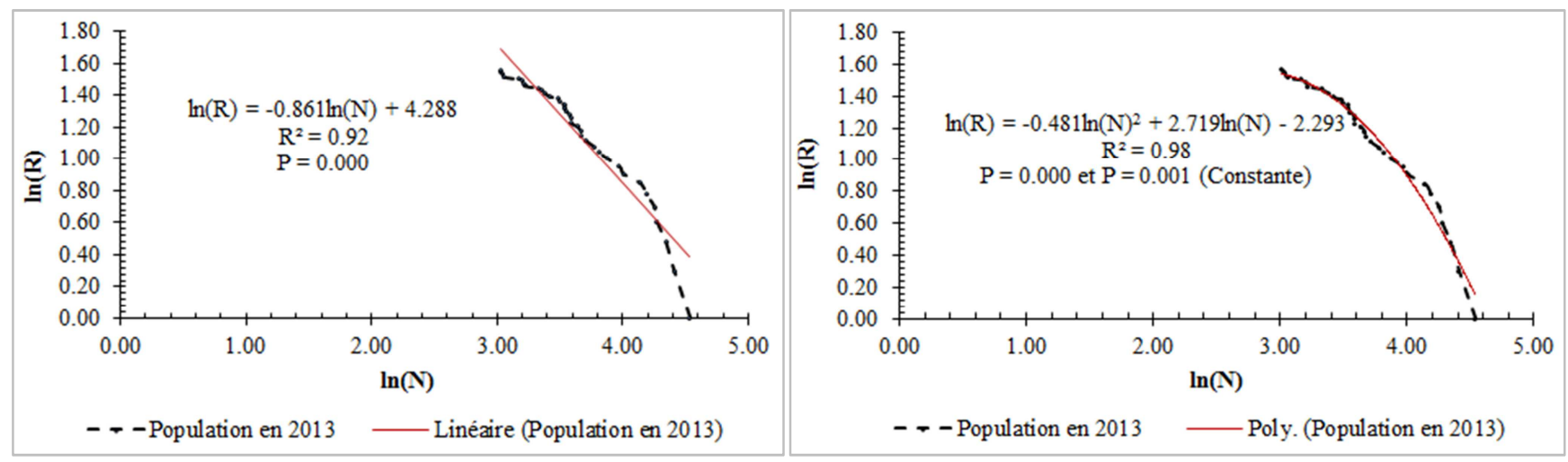

Figure 7. Linear and quadratic adjustment of Parakou districts in 2013. (Sample size: 37).

The population explosion is observed in Parakou in the 2000 s and was characterized by a parallel space consumption. All this in a batch and spontaneous installation of new neighbourhoods, due to the attraction of the city center on the neighbouring regions. This period also coincides with the dynamics of industrialization of the area, the revival of cotton production sector and the need for diversification of agricultural production in the country [30], [31]. The number of districts with more than 10000 inhabitants increased from 3 in 2002 to 8 in 2013 (1550 493 to $7071 \pm 19733$ ) accompanied by a decrease in small neighbourhoods of 16 to 12 between 2002 and 2013. The coefficient hierarchy is less than 1 in this decade and shows a collective increase in small districts (Sawararou, Koroborou, Beyarou...) to the minimum threshold of 1,000 inhabitants in 2013.

The overall hierarchy of neighbourhoods in Parakou therefore remained stable since the 70 s date and shows that despite the scale of analysis, Literature findings on asymptotic movements of the rank-size distribution remains probable [32]. The empirical approaches of using the Pareto principle, the work is conducted following hypothetical conditions is random urban growth or endogenous urban growth determined by important exogenous shocks [33]. Quadratic plots of distribution indicate the coming into play of small sizes neighbourhoods in average each decade and the gradual reduction of growth differentials between neighbouring size districts especially in the old kernel. "Figure 8 and 9" shows an asymptotic variation of the parameters (coefficient and constants) models around the value zero as a function of time and reversal of direction of growth between these parameters and the number of scanned areas. This is a remarkable reduction in the weight of large and old neighbourhoods in the hierarchy between 2002 and 2013. This reduction can be explained by the rising of occupancy densities during this period, despite taking into account the large variations in area, particularly in administrative divisions 2 and 3 (Table 1).

Table 3. Distribution class populations [34, 35].

\begin{tabular}{lllll}
\hline Classe & $\mathbf{C}_{1}$ & $\mathbf{C}_{2}$ & $\mathbf{C}_{3}$ & $\mathbf{C}_{4}$ \\
\hline Intervalle & $<0.18 \mathrm{~m}$ & $0.18 \mathrm{~m} \leq \mathrm{x}<0.25 \mathrm{~m}$ & $0.25 \mathrm{~m} \leq \mathrm{x}<0.40 \mathrm{~m}$ & $0.40 \mathrm{~m} \leq \mathrm{x}<\mathrm{m}$ \\
\hline
\end{tabular}

$\mathrm{m}$ : population moyenne par quartier. X: population u quartier.

O. Thomas and M. Djaouga [23] found that despite the method and analysis criteria, in the town of Parakou, the number of districts converged on an identifiable common threshold among the leading districts since the 70s and 90s with a high concentration of middle class $\mathrm{C}_{4}$ around the average size. The Figure 10 shows that, the last two decades were marked by the emergence of new small and mediumsize class $C_{1}$ to $C_{3}$. Class $C_{4}$ still remains dominant and this can be explained by the fact that the socio-historical economic positioning of the central core retains his role polarizer overnight 2000 s, but this role is fading slowly in the decade 2002 to 2013 and will continue as well giving likely effects of investment policy choices in the area, and the decrease in land access costs in the Northeast and Southeast directions downtown on the basin of the Okpara, everything indicated the rise of class $\mathrm{C}_{1}$ and $\mathrm{C}_{3}$ during this decade.

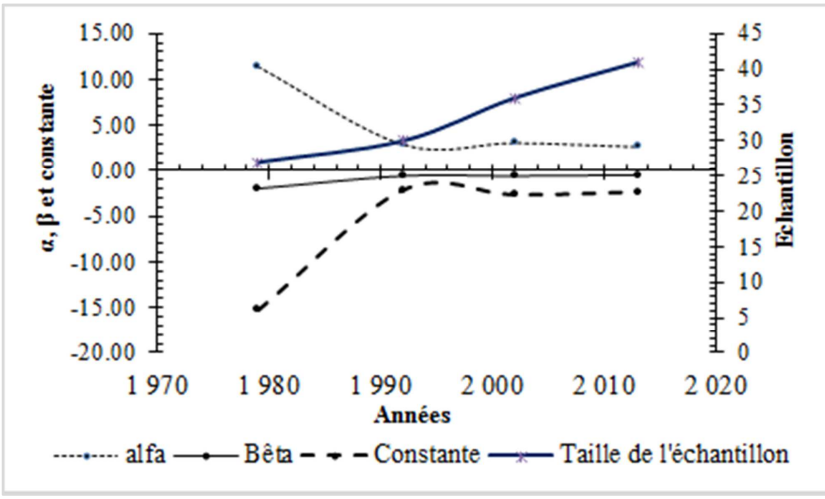

Figure 8. Variation in time, the quadratic model fitting parameters. 


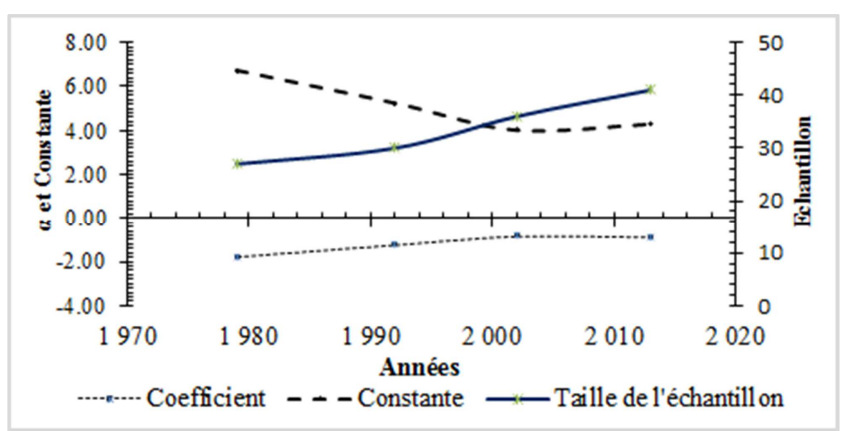

Figure 9. Variation in time, the linear model fitting parameters.

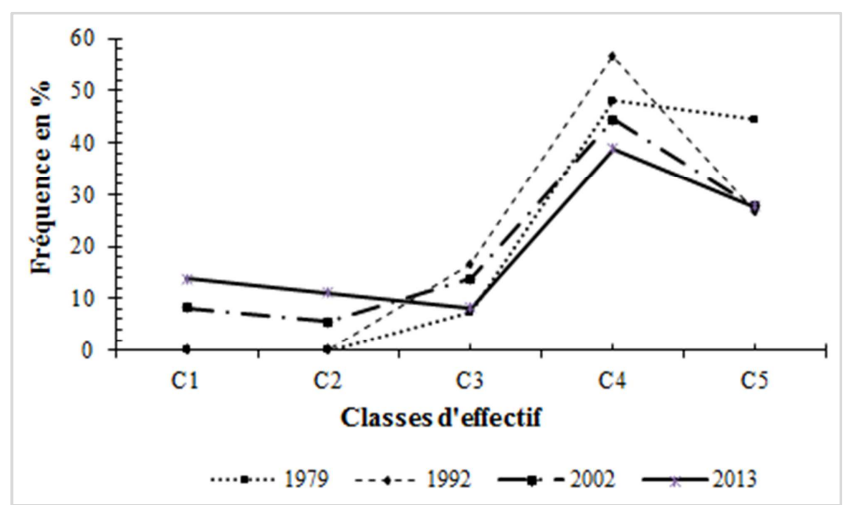

Figure 10. Distribution of districts in effective classes according Black and Henderson (2003); Shaffar and Dimou, (2012).

\section{Conclusion}

Works on urban assessment and population distribution patterns in developing countries and particularly in Benin, are few. This work is contributing to the enrichment of information on this topic in Parakou city from a statistical analysis and Zipf's law for not only a small number of individual but also with variables low amplitude compared to the work on European cities, American, and Asian. From 70s to today, Parakou experienced first general growth period in the three districts around the old kernel. This period, before the years of disinterest in districts 1 and 3; but over the last decade, simultaneous recovery observed installation within three districts accompanied by a high consumption of land. This situation occurs mainly on the side of the Okpara where land use is carried in the directions Northeast and Southeast. Given the socio-economic role of Kpassa restraint to Parakou, it is urgent to assess the potential impacts of this population increase for the redefinition of planning policies and protection of natural resources in Benin.

\section{References}

[1] A. Mama, B. Sinsin, C. De Carnnière, and J. Bogaert, "Anthropisation et dynamique des paysages en zone soudanienne au nord du Bénin," TROPICULTURA, vol. 31, no. 1, pp. 78-88, 2013.

[2] E. K. Ahoussi, N. Soro, A. M. Kouassi, G. Soro, Y. B. Koffi, and Zade, "Application des méthodes d'analyses statistiques multivariées à l'étude de l'origine des métaux lourds $\left(\mathrm{Cu}^{2+}\right.$, $\mathrm{Mn}^{2+}, \mathrm{Zn}^{2+}$ et $\left.\mathrm{Pb}^{2+}\right)$ dans les eaux des nappes phréatiques de la ville d'Abidjan," Int J Biol Chem Sci, vol. 4, no. 5, pp. 1753$1765,2010$.

[3] S. G. Eblin, A. P. Sombo, G. M. Soro, N. Aka, O. Kambiré, and N. Soro, "Hydrochimie des eaux de surface de la région d'Adiaké (sud-est côtier de la Côte d'Ivoire)," J. Appl. Biosci., vol. 75, pp. 6259-6271, 2014.

[4] A. Traoré et al., "Evaluation des paramètres physiques, chimiques et bactériologiques des eaux d'une lagune tropicale en période d'étiage : la lagune Aghien (Côte d'Ivoire)," Int $J$ Biol Chem Sci, vol. 6, no. 6, pp. 7048-7058, 2012.

[5] K. M. Yao, B. S. Metongo, A. Trokourey, and Y. Bohra, "La pollution des eaux de la zone urbaine d'une lagune tropicale par les matières oxydables (lagune Ebrié, Côte d'Ivoire)," Int J Biol Chem Sci, vol. 3, no. 4, pp. 755-770, 2009.

[6] M. K. Yao, K. B. Yao, A. Trokourey, and M. B. Soro, "Assessment of Organic Pollution in Tropical Lagoon Bay Like Lake (Tiagba Bay Lagoon, Ébrié Lagoon, Côte D'ivoire)," vol. Vol. 122, no. 3, pp. 299-311, 2014.

[7] J. Wethé, M. Radoux, and E. Tanawa, "Assainissement des eaux usées et risques socio - sanitaires et environnementaux en zones d'habitat planifié de Yaoundé (Cameroun)," VertigO - Rev. Électronique En Sci. Environ., vol. 4, no. 1, 2003.

[8] S. Soulama, A. Kadeba, B. M. I. Nacoulma, S. Traoré, Y. Bachmann, and A. Thiombiano, "Impact des activités anthropiques sur la dynamique de la végétation de la réserve partielle de faune de Pama et de ses périphéries (sud-est du Burkina Faso) dans un contexte de variabilité climatique," $J$. Appl. Biosci., vol. 87, pp. 8047-8064, 2015.

[9] C. Parent-Raoult and J.-C. Boisson, "Impacts des rejets urbains de temps de pluie (RUTP) sur les milieux aquatiques : État des connaissances," J. Water Sci., vol. 20, no. 2, pp. 229239, 2007.

[10] T. D. Soro et al., "La variabilité climatique et son impact sur les ressources en eau dans le degré carré de Grand-Lahou (Sud-Ouest de la Côte d'Ivoire)," Géographie Phys. Environ., vol. 5, pp. 55-73, 2011.

[11] FNUAP, "State of the world population. Facing a changing world: women, population and climate. (L'état de la population mondiale. Faire face à un monde en mutation: femmes, population et climat)," New York, 2009.

[12] ONU-Habitat, "Évolution des politiques urbaines nationales. Aperçu général.” 2016.

[13] S. Jaglin, "Etalement urbain, faiblesses, densité et 'cout' de développement. Introdution,” Flux, no. 79-80, pp. 6-15., 2010.

[14] D. Pumain, "Une Théorie Géographique pour la loi de Zipf," Région Dév., vol. 36, 2012.

[15] M. Dimou and A. Schaffar, "Evolution des hiérarchies urbaines et loi de Zipf, Le cas des Balkans," Région Dév., vol. 25, pp. 65-86., 2007.

[16] G. Duranton, "Some foundations for Zipf's law: product proliferation and local spillovers," Reg. Sci. Urban Econ., vol. 36 , pp. 542-563, 2006.

[17] P. Laviolette, "La gestion des déchets ménagers, casse-tête urbain à Parakou." Université catholique de Louvain, 2007. 
[18] C. Voiron-Canicio, "Pour une approche systémique du développement durable," Dév. Durable Territ., vol. Dossier 4, p. $8,2005$.

[19] EAA, "Rapport sur l'état des lieux dans le cadre de l'appui à l'élaboration du Plan Directeur d'Assainissement de la ville de Parakou," SONEB, RAPPORT Final, 2014.

[20] R. Samuel and A. Jacques, "Décrire à grande échelle l'occupation des sols urbains par photo- interprétation. Réflexion méthodologique et expérimentation en Provence," Sud-Ouest Eur., vol. Les Observatoires Hommes-Milieux, no. 33, pp. 25-40, 2012.

[21] E. C. Craig, A. Jeffery, and L. Kang Shou, "Modeling Growth and Predicting Future Developed Land in the Upstate of South Carolina," Saluda-Reedy Watershed Consort., p. 19, Nov. 2007.

[22] Zipf, "Human Behaviour and the principle of least effort. An introduction to humn ecology.," Hafner P, vol. reprinted 1965, p. $573,1949$.

[23] O. Thomas and M. Djaouga, "La question de l'urbanisation et de l'offre de service au Bénin en Afrique de l'Ouest.," 2008.

[24] J. P. Collin and J. Mongeau, "Quelques aspects démographiques de l'étalement urbain à Montréal de 1971 à 1991 et leurs implications pour la gestion de l'agglomération," Cah. Qué. Démographie, vol. 21, no. 2, pp. 5-30, 1992.

[25] G. Nouatin and F. Bachabi, "Urbanisation et viabilité de l'activité maraîchère: cas d'une ville à statut particulier au Bénin (Parakou)," Vertigo- Rev. Électronique En Sci. Environ., vol. 10, no. 2, Sep. 2010.

[26] C. Enault, "Simulation de l'étalement urbain de Dijon en 2030: approche systémique de la dynamique gravitaire villetransport," Cybergeo Eur. J. Geogr., vol. 592, p. 29, 2012.
[27] G. Demoures and P. Sun, "Distance aux activités et étalement urbain," Polytech tour - CITERES, Projet de fin d'étude, 2012.

[28] D. C. Gouamene, K. R. Oura, and S. Ouattara, "Etalement Urbain Et Tensions Foncieres Dans Les Villages Peripheriques De Daloa (Centre-Ouest, Cote d'Ivoire)," Eur. Sci. J., vol. 13, no. 35, Décembre 2017.

[29] S. Vermeulin and S. Khan, "Mobilités urbaines et durabilité dans les villes sud- africaines," Environ. Urbain, vol. 4, p. 19, 2010 .

[30] A.-R. Abdoulaye and A. Y. M. A. Ramanou, "Urban MarketGardening in Parakou (Republic of Benin): Spatial Dynamics, Food Security, Protection of the Environment and Creation of Employments," J. Geosci. Environ. Prot., vol. 3, pp. 93-103, 2015.

[31] J. Egah, M. Nasser Baco, and I. Moumouni, "Dynamique de gestion de la biodiversité d'igname face au développement du vivrier marchand au nord- Bénin," VertigO Rev. Electronique En Sci. L'environnement, vol. 12, no. 3, 2012.

[32] M. Dimou and A. Schaffar, "Urban hierarchies and city growth in the Balkans," Urban Stud., vol. 46, no. 13, pp. 2891-2906., 2009.

[33] M. Dimou and A. Schaffar, "La croissance urbaine est-elle aléatoire? Les effets des chocs exogènes sur la distribution rang- taille des villes de la péninsule balkanique," presented at the Communication au colloque GDRI-CNRS DREEM, Istanbul, mai-2009.

[34] D. Black and J. V. Henderson, "Urban evolution in the USA," J. Econ. Geogr., vol. 3, no. 4, pp. 343-372, 2003.

[35] OCDE, "La croissance urbaine chinoise: convergence ou marche aléatoire ?," Eur. J. Dev. Res., vol. 25, no. 1, pp. 154$167,2012$. 